PERM JOURNAL OF PETROLEUM AND MINING ENGINEERING ВЕСТНИК ПНИПУ. ГЕОЛОГИЯ. НЕФТЕТАЗОВОЕ И ГОРНОЕ ДЕЛО ISSN 2224-9923 Volume/Tom 19 №4 2019

http://vestnik,pstu.ru/geo/

UDC 622.276.63:550.8.023

Article / Статья

(C) PNRPU / ПНИПУ, 2019

\title{
THE INFLUENCE OF ACID CONCENTRATION AND INJECTION RATE ON THE WORMHOLE DEVELOPMENT IN FORMATION CONDITIONS. A LABORATORY STUDY
}

\section{R.A. Khuzin, G.P. Khizhniak ${ }^{1}$}

Gazpromneft Badra B.V. (335 Royal Tulip Al-Rashid Hotel, Baghdad, 8070, Republic of Iraq)

${ }^{1}$ Perm National Research Polytechnic University (29 Komsomolskiy av., Perm, 614990, Russian Federation)

\section{ЛАБОРАТОРНЫЕ ИССЛЕДОВАНИЯ ВЛИЯНИЯ КОНЦЕНТРАЦИИ И СКОРОСТИ ЗАКАЧКИ КИСЛОТЫ НА РАЗВИТИЕ ЧЕРВОТОЧИН ПРИ ПЛАСТОВЫХ УСЛОВИЯХ}

\section{Р.А. Хузин, Г.П. Хижняк ${ }^{1}$}

Газпромнефть Бадра Б.В. (8070, Ирак, г. Багдад, Ройял Тьюлип Аль-Рашид Хоутел, офис 335)

${ }^{1}$ Пермский национальный исследовательский политехнический университет (614990, Россия, г. Пермь, Комсомольский проспект, 29)

Received / Получена: 11.06.2019. Accepted / Принята: 01.11.2019. Published / Опубликована: 27.12.2019

\section{Key words:}

carbonates, limestone, dolomite, hydrochloric acid treatment, wormholes, near-wellbore formation region, injection rate, temperature, pressure, acid concentration, saturation, composition, flow properties, mineral composition, pore structure, vugginess, perforation, sample size, flow geometry, Badra, Iraq, core, diffraction analysis, computed tomography.

Ключевые слова

карбонаты, известняк, доломит, солянокислотная обработка червоточины, околоскважинная зона пласта, скорость закачки, температура, давление, концентрация кислоты, насыщение, композиционный состав, фильтрационные свойства, минеральный состав, структура порового пространства, кавернозность, перфорация, размер образцов, геометрия потока, Бадра, Ирак, керн, дифракционный анализ, компьютерная томография.
Carbonate rocks contain about $60 \%$ of global oil and gas reserves. Stimulation of wells tapping into carbonate reservoirs is often performed using hydrochloric acid treatments based on the chemical reaction of hydrochloric acid with carbonate minerals.

Carbonate reservoirs generally exhibit significant inhomogeneity, therefore the acid being injected into the formation causes uneven rock dissolution in the near-wellbore region, resulting in the emergence of highly conductive flow channels (wormholes) with complex geometry. They ensure a good hydrodynamic connection between the well and the formation. Each specific rock-acid compound system has an optimum injection rate which can help form long weakly ramified wormholes at minimum acid injection volume. The optimum injection rate value is influenced by many factors, such as pressure, temperature, acid concentration, solution composition, mineral composition of rock etc. As of today, laboratory research is the main method to determine the optimum parameters for treating the near-wellbore formation region with acid. The paper summarises the results of the analysis examining the influence of various factors on the optimum injection rate and the amount of injected pore volumes of an acid compound until a wormhole breakthrough. It is shown that the factors have a cumulative effect on the effectiveness of the acid treatment and have to be considered simultaneously in laboratory tests. The results of the performed analysis have been taken into account when planning further laboratory research.

Within the design scope of hydrochloric acid treatments in wells of one of Iraq's carbonate fields, laboratory tests have been conducted to assess the impact of acid concentration and injection rate on the effectiveness of acid stimulation in the conditions that were expected in case of the hydrochloric acid treatment. The determined injection parameters help obtain an optimum structure of wormholes at a minimum acid injection volume.

The results of the performed research have been successfully used to design hydrochloric acid treatments in wells of the field under study.

Карбонатные породы содержат около 60 \% мировых запасов нефти и газа. Для стимуляции скважин, вскрывающих карбонатные коллекторы, широко используются солянокислотные обработки, в основе которых лежит химическая реакция соляной кислоты с карбонатными минералами

Карбонатные коллекторы, как правило, обладают значительной неоднородностью, поэтому при закачке кислоты в пласт в призабойной зоне скважины происходит неравномерное растворение породы кислотой, в результате чего образуются высокопроводящие каналы фильтрации (червоточины) сложной геометрии, обеспечивающие хорошую гидродинамическую связь скважины с пластом. Для определенной системы «порода - кислотный состав» существует оптимальная скорость закачки, которая позволяет получать длинные малоразветвленные червоточины при минимальном объеме закачки кислоты. На величину оптимальной скорости закачки оказывает влияние множество факторов, таких как давление, температура, концентрация кислоты, композиционный состав раствора, минеральный состав породы и т.д. Основным методом определения оптимальных параметров кислотного воздействия на околоскважинную зону пласта на сегодняшний день являются лабораторные эксперименты.

В работе приведены сводные результаты анализа влияния различных факторов на оптимальную скорость закачки и величину прокачанных поровых объемов кислотного состава до момента выхода червоточины из образца. Показано, что факторы комплексно влияют на эффективность кислотного воздействия и требуется их одновременный учет при проведении лабораторных экспериментов. Результаты выполненного анализа были учтены при планировании дальнейших лабораторных исследований.

В рамках проектирования солянокислотных обработок на скважинах одного из карбонатных месторождений Ирака проведены лабораторные опыты по оценке влияния концентрации кислоты и скорости закачки на эффективность кислотного воздействия при условиях, ожидаемых в случае применения солянокислотной обработки. Определены параметры закачки, позволяющие получать оптимальную структуру червоточин при минимальном объеме закачки кислоты.

Результаты выполненных исследований успешно использовались при проектировании солянокислотных обработок на скважинах рассмотренного месторождения.

Rinat A. Khuzin (Author ID in Scopus: 57205219438) - Head of Development Department (tel.: +007 968 662 14 56, e-mail: Khuzin.ra@gazpromneft-badra.com). The contact person for correspondence.

Grigoriy P. Khizhnyak (Author ID in Scopus: 36711848000) - Doctor of Engineering, Associate Professor at the Department of Oil and Gas Technologies (tel.: +007 342 219 8292 , e-mail: xgp@mail.ru).

Хузин Ринат Альвертович - начальник управления разработки (тел.: +007 96866214 56, e-mail: Khuzin.ra@gazpromneft-badra.com). Контактное лицо для переписки.

Хижняк Григорий Петрович - доктор технических наук, доцент, заведующий кафедрой нефтегазовых технологий (тел.: +007 3422198292, e-mail: xgp@pstu.ru) 


\section{Introduction}

Carbonate rocks contain about $60 \%$ of global oil and gas reserves [1-4]. These rocks mostly include sedimentary formations consisting of $50 \%$ and more carbonate minerals [5], the major part of which are calcite $\left(\mathrm{CaCO}_{3}\right)$ and dolomite $\left(\mathrm{CaMg}\left(\mathrm{CO}_{3}\right)_{2}\right)$. To intensify a fluid influx to a well tapping into the carbonate reservoir, hydrochloric acid treatments (HATs) of the near-wellbore formation region (NWFR) are widely used. This stimulation type is based on the interaction of acid solutions, mostly derived from hydrochloric acid $(\mathrm{HCl})$, with carbonate minerals. As multiple laboratory tests have shown, the injection of acid into the carbonate reservoir results in the formation of the so-called wormholes, or highly permeable channels with complex geometry that penetrate the formation to the depth of several meters and thus ensure a good hydrodynamic connection between the formation and the wellbore (Fig. 1).

The shape and penetration depth of wormholes depends on many factors, such as acid solution composition, mineral composition of the rock, formation saturation, rock inhomogeneity, injection rate, well completion type etc.

In HAT design, one of the main goals is to select optimum acid compounds and injection parameters for the conditions of a specific deposit, to obtain long weakly ramified wormholes at a minimum acid injection volume.

As of today, the main method for studying the processes occurring during a HAT is laboratory tests. As a rule, it is difficult to design the tests so as to consider all possible factors influencing the acid treatment effectiveness. The analysis has shown that the purpose of the majority of the published works was to study the influence of individual factors on the acid stimulation effectiveness. However, a possible simultaneous influence of several factors was not considered. Besides, in most works, the tests were performed in conditions that vastly varied from the real HAT conditions. Practical use of such results can lead to a significant error in the obtained estimates.

The current task is to determine the factors that have to be considered simultaneously in laboratory studies and to obtain correlation dependencies that enable practical forecasting of the wormhole development processes in the near-wellbore formation region.
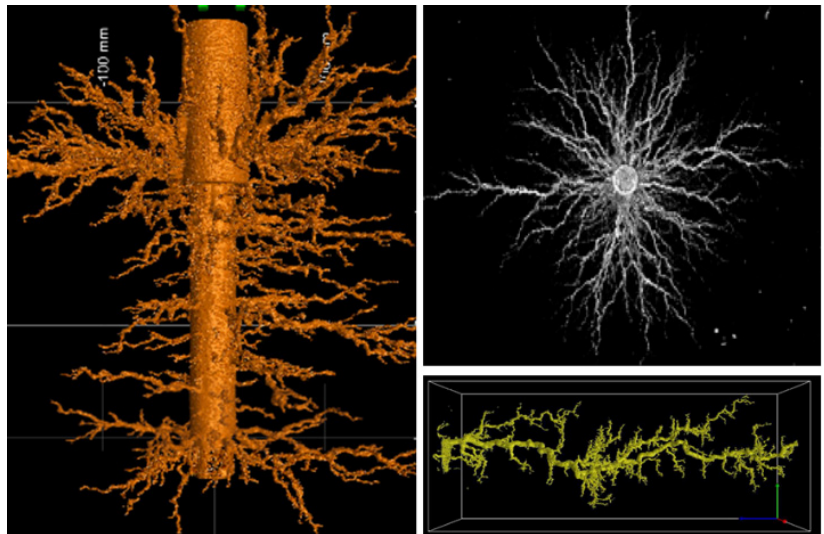

Fig. 1. 3D-visualization of wormholes based on computed tomography $[6-8]$

\section{A concise analysis of factors influencing the acid stimulation effectiveness}

Acid stimulation effects on carbonate formations have been extensively studied in the literature. As a rule, the authors use laboratory tests to research the influence of one or several factors on the acid treatment effectiveness. Such factors include:

- acid injection rate and volume [9-16];

- stimulation temperature $[9,10,17,18]$;

- hydrochloric acid concentration $[9,10,14$, 17-19];

- stimulation pressure [20];

- fluid saturation of samples [21-24];

- composition of injected solutions $[9,14,15,17$, $18,23,25-49]$;

- size of samples [17, 19, 45];

- flow geometry (radial, linear) $[6,10,11,50-53]$;

- mineral composition (calcite, dolomite) [9, 54];

- flow properties and pore structure $[10,14,17$, $28,40,52,54-60]$;

- influence of well completion technology and stimulation features [61-63].

It does not seem possible to review the entire scope of the performed studies, due to a large variety of acid compounds used, conditions emerging during the injection, composition of NWFR saturating fluids, pore structure, rock mineral composition etc.

As multiple experiments have shown, any given rock-acid compound system can produce various rock dissolution structures depending on the injection rate (Fig. 2):

- face dissolution;

- formation of conic wormholes; 
- formation of dominant wormholes (long, narrow, weakly ramified wormholes - optimum result);

- strongly ramified wormhole structure;

- uniform dissolution.

At the minimum injection rates, the entire solution reacts upon entry into the sample and dissolves it completely. In this case, to achieve a certain penetration depth, a significant volume of acid compound (AC) is required. At a higher injection rate, the acid penetrates the rock and forms a dissolution channel - a wormhole; however, a significant portion of the solution reacts with the wormhole walls, thereby creating its conic structure. The AC volume to achieve a certain depth of wormhole penetration is significantly lower compared to the face dissolution. If the injection rate is sufficient to deliver the $\mathrm{AC}$ to the wormhole tip, then the reacting results in its further lengthening and formation of the so-called dominant wormhole which develops through dissolution of pores with a maximum diameter. This structure is the most optimum one since it helps reach the required penetration depth at the minimum injection volume. Higher injection rates lead to the formation of ramifications from the dominant wormhole since the solution becomes pressured into the minor pores and the length-wise growth of the wormhole slows down, hence increasing the overall AC volume required to achieve the necessary penetration depth. At extremely high injection rates, the acid penetrates even smaller pores resulting in their uniform dissolution and an increase of the required $\mathrm{AC}$ volume to achieve the required penetration depth.

The results of laboratory tests in their most simple interpretation can be presented as a dependence of the number of injected pore volumes of the solution until a wormhole breakthrough $(P V B T)$ on the injection rate $(V i)$ (Fig. 3). The figure shows the results of several tests performed in various conditions. The minimum point on each curve determines the optimum injection rate.

In order to determine the factors that have to be considered in the laboratory tests for studying the acid stimulation effectiveness, an analytical review of the published research has been performed.

Table 1 summarises the results of the analysis examining how different factors impact on the optimum injection rate and $P V B T$ value, along with the justification of their importance and the possibility to take them into account in the laboratory conditions for commercial-scope tests.

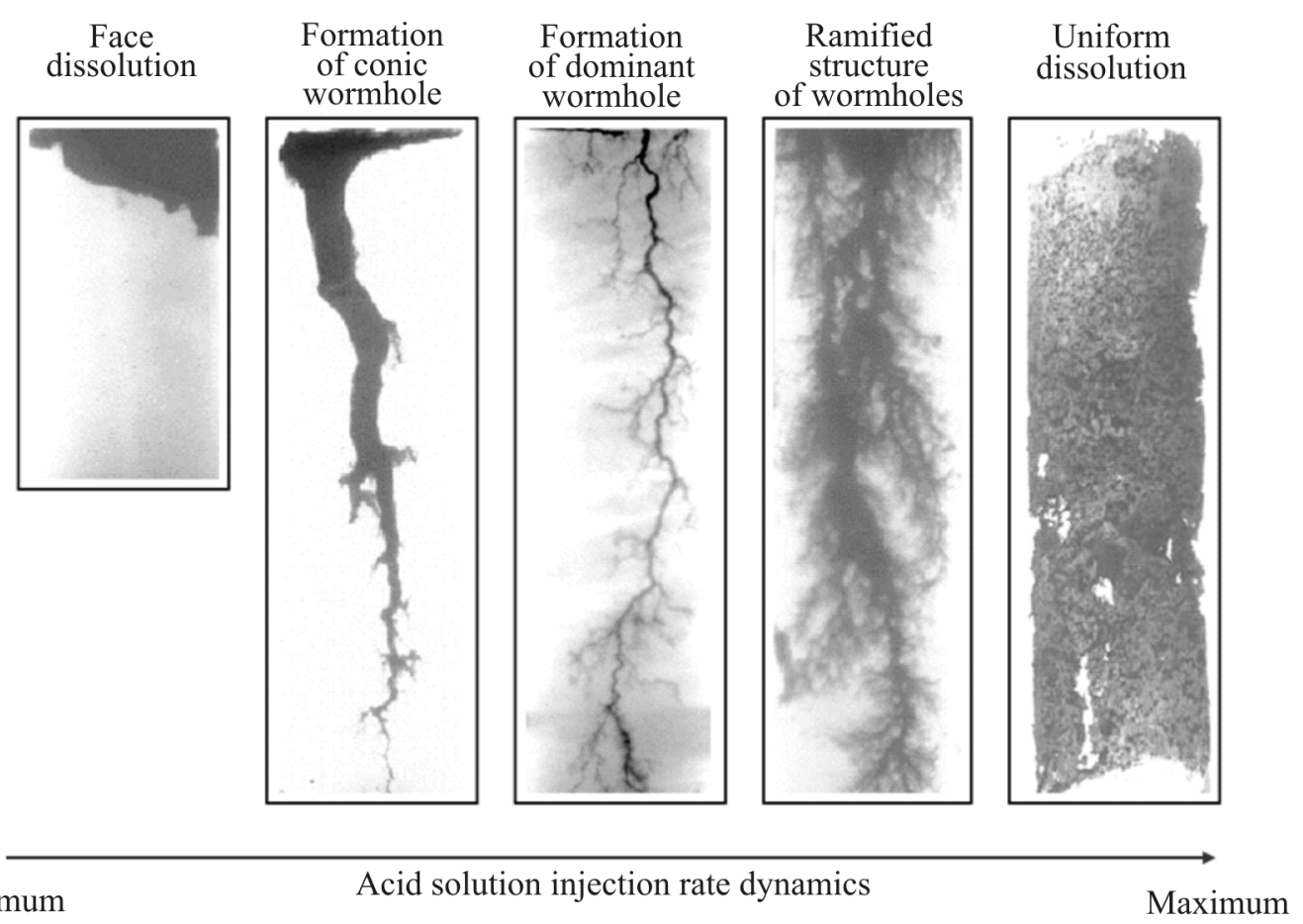

Fig. 2. The appearance of dissolved pore space obtained by injection of hydrochloric acid into the linear core sample at various injection rates [12] 


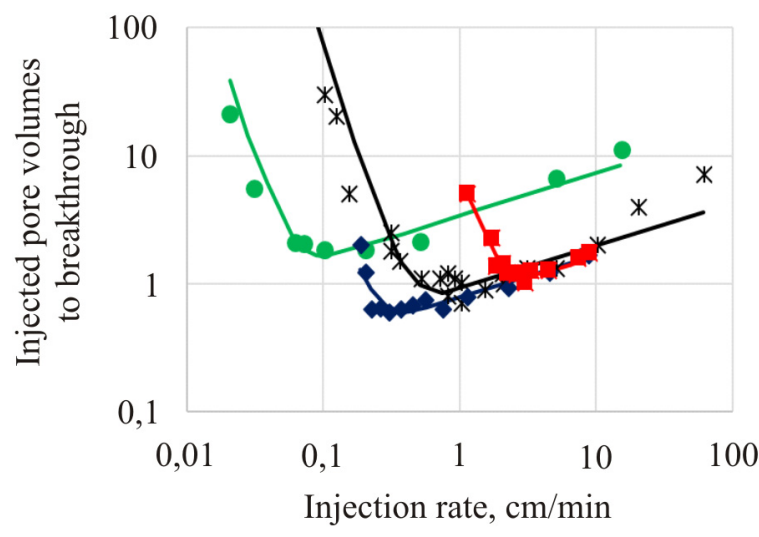

Fig. 3. The results of the laboratory tests to assess the wormhole development effectiveness [64]

As evident from Table 1, all considered factors, except pressure (in case it exceeds the pressure of the generated $\mathrm{CO}_{2}$ gas transition to the liquid condition or the supercritical fluid condition), have a high impact on the results obtained in the course of the laboratory studies. It suggests that they have to be taken into account during test design. The dynamics of some of the factors can have a divergent impact on the optimum injection rate and $P V B T$ value. Besides, a simultaneous manifestation of different factors, which is normally observed in practice, can also result in divergent dynamics of the optimum injection parameters. It is difficult to take into account some of these factors in mass laboratory tests due to the limitation of sample size and used equipment. To take these factors into account, it is necessary to use the correlations that are discussed in the research literature.

The analysis has shown that to obtain the correlation dependencies that enable practical forecasting of the wormhole development in NWFR, a laboratory test have to be conducted in the conditions that approximate to those expected during the HAT, and on representative core samples from the specific field.

Table 1

The summary results of the analysis of various factors impact on the optimum injection rate and $P V B T$ value

\begin{tabular}{|c|c|c|c|c|c|}
\hline \multicolumn{2}{|c|}{ Factor } & $\begin{array}{c}\text { Importance } \\
\text { of consideration } \\
\text { in laboratory tests }\end{array}$ & $\begin{array}{l}\text { Optimum injection } \\
\text { rate dynamics } \\
\text { vs. parameter growth }\end{array}$ & $\begin{array}{l}P V B T \text { dynamics vs. } \\
\text { parameter growth }\end{array}$ & $\begin{array}{l}\text { Possibility to consider } \\
\text { HAT expected data } \\
\text { in laboratory tests }\end{array}$ \\
\hline \multicolumn{2}{|c|}{ Temperature } & High & Increase & Divergent & Possible \\
\hline \multicolumn{2}{|c|}{$\mathrm{HCl}$ concentration } & High & Increase & Decrease & Possible \\
\hline \multirow{2}{*}{ Pressure } & below 69 atm (1000 psi) & High & Decrease & Increase & Possible \\
\hline & above 69 atm (1000 psi) & Low & Low impact & Low impact & - \\
\hline \multicolumn{2}{|c|}{ Hydrocarbon saturation } & High & Decrease & Decrease & Possible \\
\hline \multicolumn{2}{|c|}{ Injected fluid composition } & High & Divergent & Divergent & Possible \\
\hline \multicolumn{2}{|c|}{$\begin{array}{l}\text { Impact of flow properties, pore } \\
\text { structure and mineral composition }\end{array}$} & High & Divergent & Divergent & Possible \\
\hline \multicolumn{2}{|c|}{ Impact of sample size } & High & Increase & Increase & $\begin{array}{c}\text { Use of samples } \\
\text { commensurate with } \\
\text { NWFR is problematic }\end{array}$ \\
\hline \multicolumn{2}{|c|}{$\begin{array}{l}\text { Impact of perforation channels } \\
\text { purity }\end{array}$} & High & Decrease & Decrease & $\begin{array}{c}\text { Use of samples } \\
\text { commensurate with } \\
\text { influence of perforation } \\
\text { channels in NWFR } \\
\text { is problematic }\end{array}$ \\
\hline \multicolumn{2}{|c|}{$\begin{array}{l}\text { Impact of jet effect due to the well } \\
\text { stimulation features }\end{array}$} & High & Decrease & Decrease & $\begin{array}{c}\text { Use of samples } \\
\text { commensurate with } \\
\text { NWFR is problematic }\end{array}$ \\
\hline \multicolumn{2}{|c|}{$\begin{array}{l}\text { Transfer from linear to radial } \\
\text { samples }\end{array}$} & High & Increase & Increase & $\begin{array}{c}\text { Use of samples } \\
\text { commensurate with } \\
\text { NWFR is problematic }\end{array}$ \\
\hline
\end{tabular}




\section{Laboratory study of the concentration and injection rate influence on hydrochloric acid solutions in formation conditions of one of the Iraqi fields}

\section{Object of the study}

The object of the study is a field located in Zagros oil province, Iraq. The main production object is the Mauddud Upper Cretaceous formation having eight determined strata (A, B, C, D, E, F, G, H). The main volume of the reserves (about $80 \%$ ) is concentrated in B and D strata that produce up to $94 \%$ of the field oil. Due to these reasons, the research was focused on these strata. The productive strata are represented by carbonate porous type reservoirs containing light crude oil. Due to the geological peculiarities, the productive strata penetration occurs at significant overbalance pressure, resulting in NWFR clogging. As the experience of testing in the first development wells has shown, to obtain a commercial oil influx, it is necessary to stimulate the wells with acid compounds. The laboratory tests using core samples selected from the development wells have been conducted in order to study the strata properties and optimize stimulation of the producing wells.

\section{Determining the test conditions}

When determining the conditions for the laboratory tests that suggested an injection of acid compounds into core samples, the aforementioned analysis of factors influencing the test results have been taken into account. Therefore, it was decided to conduct the experiments in the conditions reproducing those expected in the well stimulation (temperature, pressure, saturation, reservoir fluids viscosity, acid composition and concentration). The experiments were aimed at assessing the influence of the acid solution injection rate and concentration.

\section{Samples conditioning}

Prior to checking if the samples are representative, a CT scanning was performed, the samples were cleaned and conditioned for the research.

In order to determine the quantitative composition of minerals contained in the samples, X-ray diffraction analysis (XRD) was performed. The analysis results for 18 samples (Table 2) have shown that the rock consists of micritic limestone with prevailing calcite (more than $95 \%$ ) and a minor amount of quartz and dolomite.

Table 2

The results of X-ray diffraction analysis of the core samples

\begin{tabular}{|c|c|c|c|c|c|c|c|}
\hline Well & Sample Sr. No. & Depth, m & Stratum & Calcite & Quartz & Dolomite & Total \\
\hline \multirow{10}{*}{ W-1 } & 27 & 4520.6 & $\mathrm{~B}$ & 99.6 & 0.4 & 0 & 100 \\
\hline & 40 & 4522.6 & $\mathrm{~B}$ & 99.6 & 0.4 & 0 & 100 \\
\hline & 52 & 4524.6 & $\mathrm{~B}$ & 99 & 1.0 & 0 & 100 \\
\hline & 72 & 4527 & $\mathrm{~B}$ & 99.3 & 0.7 & 0 & 100 \\
\hline & 84 & 4528.4 & $\mathrm{~B}$ & 99.6 & 0.4 & 0 & 100 \\
\hline & 91 & 4530.2 & B & 99.4 & 0.6 & 0 & 100 \\
\hline & 164 & 4600.9 & $\mathrm{~B}$ & 99.5 & 0.5 & 0 & 100 \\
\hline & 181 & 4605.1 & B & 99.5 & 0.5 & 0 & 100 \\
\hline & 192 & 4606.3 & $\mathrm{D}$ & 99.3 & 0.7 & 0 & 100 \\
\hline & 200 & 4607.4 & $\mathrm{D}$ & 99.5 & 0.5 & 0 & 100 \\
\hline \multirow{7}{*}{ W-2 } & 5 & 4581.5 & $\mathrm{D}$ & 95.6 & 0.4 & 4 & 100 \\
\hline & 10 & 4582.7 & $\mathrm{D}$ & 99.5 & 0.5 & 0 & 100 \\
\hline & 11 & 4582.8 & $\mathrm{D}$ & 99.5 & 0.5 & 0 & 100 \\
\hline & 17 & 4583.4 & $\mathrm{D}$ & 99.6 & 0.4 & 0 & 100 \\
\hline & 47 & 4586.8 & $\mathrm{D}$ & 99.5 & 0.5 & 0 & 100 \\
\hline & 58 & 4589.3 & $\mathrm{D}$ & 99.6 & 0.4 & 0 & 100 \\
\hline & 70 & 4590.6 & $\mathrm{D}$ & 99.6 & 0.4 & 0 & 100 \\
\hline W-3 & 56 & 4601.1 & $\mathrm{D}$ & 99.1 & 0.9 & 0 & 100 \\
\hline
\end{tabular}


To assess the influence of the acid concentration and injection rate on the wormhole formation, the samples were selected the way to describe average parameters of the two main strata, as per Table 3.

After the main parameters were measured, the sample was saturated with formation water to $100 \%$ using a saturator. Then, to obtain residual water saturation, it was saturated with an artificial oil sample with viscosity equivalent to the formation oil, at the formation temperature and pressure, using an ultracentrifuge. Afterwards, the sample was placed into the testing apparatus and tested in the conditions replicating those in the formation: overburden pressure - $1098.94 \mathrm{~atm}$; pore pressure $-501.7 \mathrm{~atm}$; effective pressure - $597.24 \mathrm{~atm}$; oil viscosity $0.37 \mathrm{cP}$; oil viscosity $-0.569 \mathrm{cP}$; formation temperature $-120^{\circ} \mathrm{C}$.

\section{Testing to assess the acid concentration influence on wormhole formation}

Prior to the acid injection, the effective permeability to oil was assessed.

During the injection, the pressure differential between sample entry and exit was measured. The injection of acid with various concentrations was performed with the flow rate of $1 \mathrm{~cm}^{3} / \mathrm{min}$ until a wormhole breakthrough (a rapid pressure differential decline). The injected acid volume was captured at the time of the wormhole breakthrough. Next, $2 \mathrm{~L}$ distilled water was pumped through the sample at a flow rate of $1 \mathrm{~cm}^{3} / \mathrm{min}$. After the experiment, the samples were inspected visually (with taking photographs) and analysed using micro-CT. An example the test is shown in Figure 4, $a$.

A total of three tests were performed for each stratum (B and D) with various acid concentrations $(5,10$ and $15 \%)$. The test results are shown in Table 4.

The comparison of the obtained wormhole structures is provided in Figure 5.

Testing results suggest that acid concentration influences the development of wormholes. At injection rate of $1 \mathrm{~cm}^{3} / \mathrm{min}$, the most optimum wormhole structure (long, weakly ramified, requiring a minimum volume of the injected acid compound) is formed in response to injection of $5 \%$ acid, with minimum acid volume consumed (about $1.0-1.2 \mathrm{~cm}^{3}$ in $15 \%$ acid equivalent). On the other hand, the total volume of the injected solution is minimal. The problem of acid concentration influence on the development of wormholes requires further study; specifically, it is necessary to look into the impact of injection rate at various acid concentrations.

Table 3

The basic parameters of the core samples selected

for studying the acid treatment effectiveness

\begin{tabular}{|c|c|c|c|c|c|c|c|c|}
\hline $\begin{array}{l}\text { Sample } \\
\text { Sr. No. }\end{array}$ & Depth, m & Stratum & Length, $\mathrm{cm}$ & $\begin{array}{c}\text { Sample } \\
\text { volume, } \mathrm{cm}^{3}\end{array}$ & $\begin{array}{l}\text { Pore volume, } \\
\mathrm{cm} 3\end{array}$ & Porosity, \% & $\begin{array}{l}\text { Rock matrix } \\
\text { density, } \mathrm{g} / \mathrm{cm}^{3}\end{array}$ & $\begin{array}{l}\text { Permeability } \\
\text { to gas, md }\end{array}$ \\
\hline 88 & 4528.97 & $\mathrm{~B}$ & 3.83 & 42.70 & 5.89 & 13.80 & 2.69 & 2.65 \\
\hline 90 & 4530.15 & $\mathrm{~B}$ & 3.51 & 38.98 & 6.03 & 15.50 & 2.69 & 2.75 \\
\hline 102 & 4532.24 & $\mathrm{~B}$ & 3.59 & 39.77 & 5.31 & 13.30 & 2.69 & 3.38 \\
\hline 124 & 4596.37 & $\mathrm{D}$ & 3.19 & 35.49 & 5.53 & 15.60 & 2.68 & 7.25 \\
\hline 131 & 4597.45 & $\mathrm{D}$ & 3.36 & 36.36 & 5.93 & 16.30 & 2.68 & 9.14 \\
\hline 135 & 4597.78 & $\mathrm{D}$ & 3.46 & 38.26 & 6.31 & 16.50 & 2.69 & 10.10 \\
\hline 58 & 4525.09 & $\mathrm{~B}$ & 3.30 & 36.85 & 6.25 & 17.00 & 2.69 & 3.39 \\
\hline 60 & 4525.2 & B & 3.86 & 42.93 & 7.00 & 16.30 & 2.70 & 2.94 \\
\hline 62 & 4525.43 & $\mathrm{~B}$ & 3.53 & 39.14 & 6.88 & 17.60 & 2.70 & 3.69 \\
\hline 73 & 4527.04 & $\mathrm{~B}$ & 3.51 & 39.09 & 5.60 & 14.30 & 2.70 & 2.52 \\
\hline 74 & 4527.18 & $\mathrm{~B}$ & 3.27 & 36.18 & 5.61 & 15.50 & 2.70 & 3.59 \\
\hline 105 & 4594.23 & $\mathrm{D}$ & 3.35 & 37.30 & 6.25 & 16.80 & 2.68 & 8.65 \\
\hline 112 & 4595.2 & $\mathrm{D}$ & 3.11 & 34.57 & 5.68 & 16.40 & 2.68 & 9.92 \\
\hline 115 & 4595.58 & $\mathrm{D}$ & 3.23 & 35.96 & 6.01 & 16.70 & 2.69 & 8.15 \\
\hline 118 & 4595.86 & $\mathrm{D}$ & 3.16 & 35.09 & 6.01 & 17.10 & 2.68 & 10.60 \\
\hline 128 & 4596.81 & $\mathrm{D}$ & 3.39 & 37.66 & 6.00 & 15.90 & 2.68 & 11.10 \\
\hline
\end{tabular}


Table 4

The summary results of the experiments to assess the injected acid concentration influence on the wormhole development

\begin{tabular}{|c|c|c|c|c|c|c|c|}
\hline $\begin{array}{c}\text { Sample } \\
\text { Sr. No. }\end{array}$ & Stratum & $\begin{array}{c}\text { Acid } \\
\text { concentration, } \\
\%\end{array}$ & $\begin{array}{c}\text { Effective } \\
\text { permeability } \\
\text { to oil, md }\end{array}$ & $\begin{array}{c}\text { Injection rate, } \\
\mathrm{cm} / \mathrm{min}\end{array}$ & $\begin{array}{c}\text { Injected acid volume } \\
\text { to wormhole } \\
\text { breakthrough, } \mathrm{cm}^{3}\end{array}$ & $\begin{array}{c}\text { Time to } \\
\text { wormhole } \\
\text { breakthrough, } \mathrm{s}\end{array}$ & $\begin{array}{c}15 \% \text { acid volume } \\
\text { equivalent, } \mathrm{cm}^{3}\end{array}$ \\
\hline 88 & $\mathrm{~B}$ & 5 & 1.03 & 0.090 & 3.50 & 210 & 1.167 \\
\hline 90 & $\mathrm{~B}$ & 10 & 0.98 & 0.090 & 2.50 & 150 & 1.667 \\
\hline 102 & $\mathrm{~B}$ & 15 & 1.10 & 0.090 & 2.00 & 120 & 2.000 \\
\hline 124 & $\mathrm{D}$ & 5 & 3.64 & 0.090 & 3.00 & 180 & 1.000 \\
\hline 131 & $\mathrm{D}$ & 10 & 3.61 & 0.092 & 2.25 & 135 & 1.500 \\
\hline 135 & $\mathrm{D}$ & 15 & 3.79 & 1.00 & 1.50 & 90 & 1.500 \\
\hline
\end{tabular}

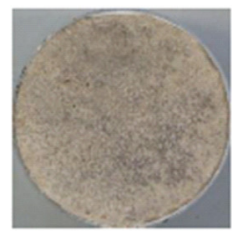

Left face of the sample before experiment

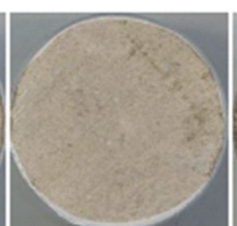

Right face of the sample of the sample of the sample

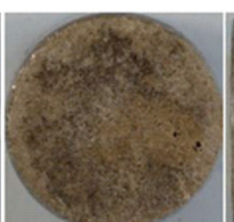

Left face

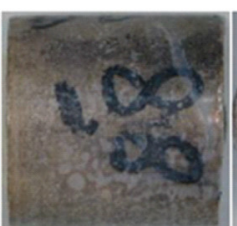

Side surface of the sample after experiment

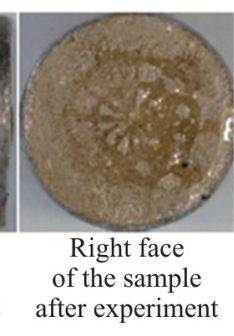

Sample schematic after experiment

Left face

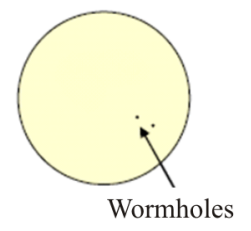

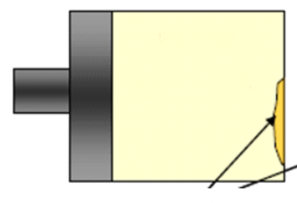

Dissolution
Right face

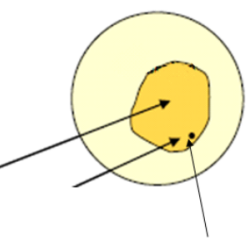

Wormholes
Visualization of wormholes based on computed tomography

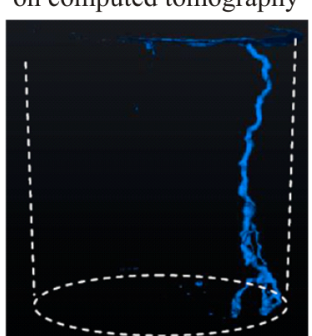

$a$

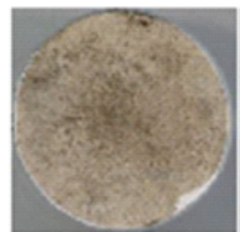

Left face of the sample before experiment

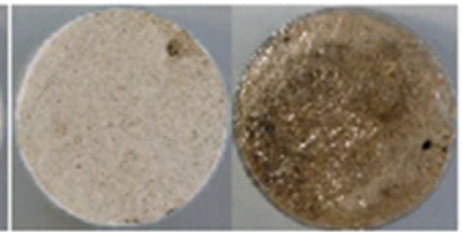

Right face of the sample

Left face of the sample before experiment after experiment

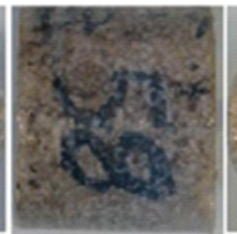

Side surface of the sample after experiment

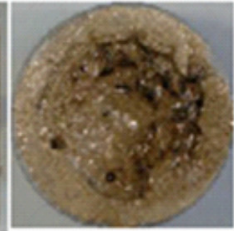

Right face after experiment of the sample

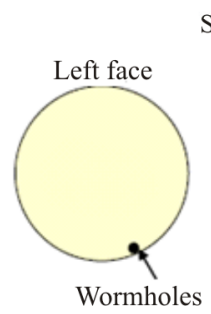

Sample schematic after experiment

Visualization

of wormholes based

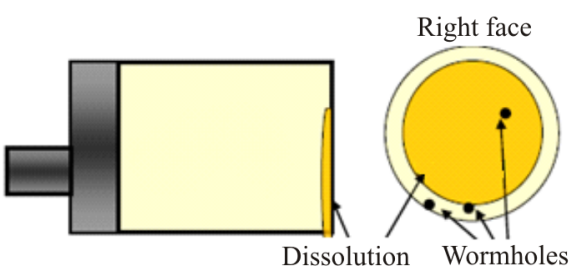

$b$

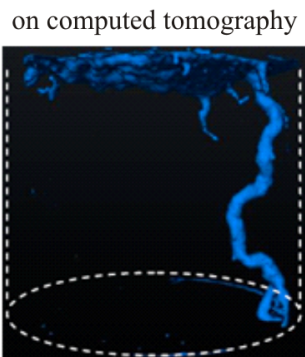

Fig. 4. The results of the experiment to assess the influence on the wormhole development: $a-5 \%$ acid concentration (sample No. 88); $b-15 \%$ acid injection rate (sample No. 58 , flow rate $-0.2 \mathrm{~cm}^{3} / \mathrm{min}$ ) 


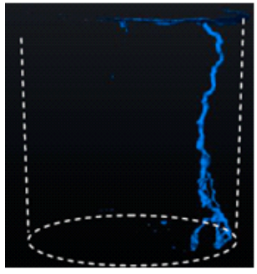

Sample 88, $5 \% \mathrm{HCl}$

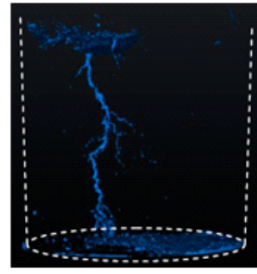

Sample 90, $10 \% \mathrm{HCl}$

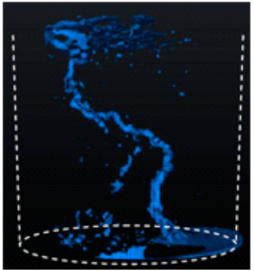

Sample 102, $15 \% \mathrm{HCl}$

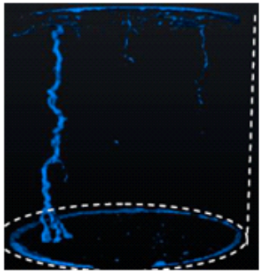

Sample 124, $5 \% \mathrm{HCl}$

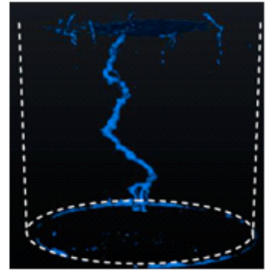

Sample 131, $10 \% \mathrm{HCl}$

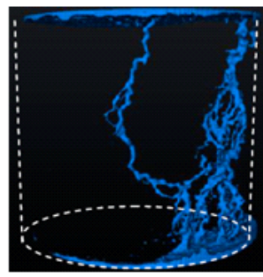

Sample 135, $15 \% \mathrm{HCl}$

Fig. 5. Comparison of wormhole development structures depending on injected acid concentration

Table 5

The summary results of the experiments to assess the $15 \%$ acid injection rate influence on the wormhole development

\begin{tabular}{|c|c|c|c|c|c|}
\hline $\begin{array}{c}\text { Sample } \\
\text { Sr. No. }\end{array}$ & Stratum & $\begin{array}{c}\text { Effective permeability to oil at } \\
\text { residual water saturation, md }\end{array}$ & $\begin{array}{c}\text { Injection rate, } \\
\mathrm{cm} / \mathrm{min}\end{array}$ & $\begin{array}{c}\text { Injected acid volume } \\
\text { to wormhole breakthrough, } \\
\mathrm{cm}^{3}\end{array}$ & $\begin{array}{c}\text { Time to wormhole } \\
\text { breakthrough, } \mathrm{s}\end{array}$ \\
\hline 60 & B & 0.92 & 0.045 & 5.75 & 690 \\
\hline 62 & B & 1.34 & 0.090 & 2.30 & 138 \\
\hline 73 & B & 0.90 & 0.449 & 2.50 & 15 \\
\hline 74 & B & 1.16 & 0.904 & 2.00 & 120 \\
\hline 102 & B & 1.10 & 0.090 & 3.50 & 420 \\
\hline 112 & D & 4.36 & 0.045 & 2.00 & 120 \\
\hline 115 & D & 3.81 & 0.090 & 4.20 & 50.4 \\
\hline 118 & D & 5.36 & 0.450 & 3.00 & 1.50 \\
\hline 128 & D & 5.45 & 0.900 & 0.090 & \\
\hline 135 & D & 3.79 & & & 50 \\
\hline
\end{tabular}

\section{Testing to assess the acid injection rate influence on wormhole formation}

The tests were conducted at formation conditions. During injection, the pressure differential between sample entry and exit was measured. Injection of acid with the most commonly used concentration of $15 \%$ was performed at different flow rates until a wormhole breakthrough (rapid pressure differential decline). Injected acid volume was captured at the time of the wormhole breakthrough. Next, 2L distilled water was pumped through the sample at the same flow rate as the acid injection. After the experiment, the samples were inspected visually (with taking photographs) and analysed using microCT. An example of the test is shown in Figure 4, $b$.

A total of five tests were performed for each stratum (B and D). The test results are shown in Table 5.
Figure 6 illustrates the comparison of the obtained wormhole structures.

The results of the study suggest that the acid injection rate influences the development of wormholes. The most optimum structure (long weakly ramified wormholes produced at the minimum injected acid compound volume) is formed in response to the injection of acid with the injection rate of about 0.6 $\mathrm{cm} / \mathrm{min}$ (Figure 7). The experiment results for both strata can be described using the same dependency of the injected acid $P V B T$ on the injection rate.

The obtained optimum injection rate values and their corresponding injected acid volumes were used to design a HAT at producing wells in the acid treatment model developed by the authors of the paper. It helped achieve an average skin factor for the producing wells (4.7) and productive thickness sweep up to $95 \%$. The practical examples of using and modelling details are provided in [66]. 


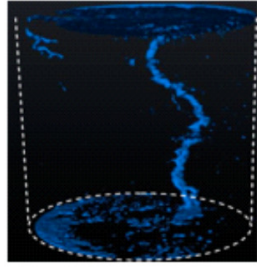

Sample 60, $Q=0,5 \mathrm{~cm}^{3} / \mathrm{min}$

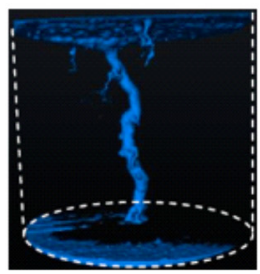

Sample 112, $Q=0,5 \mathrm{~cm}^{3} / \mathrm{min}$

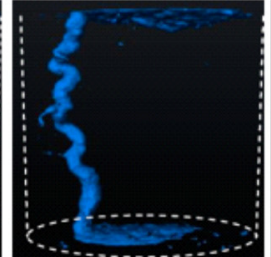

Sample 62 $Q=1 \mathrm{~cm}^{3} / \mathrm{min}$

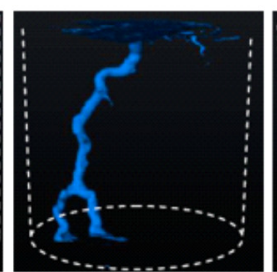

Sample 115, $Q=1 \mathrm{~cm}^{3} / \mathrm{min}$

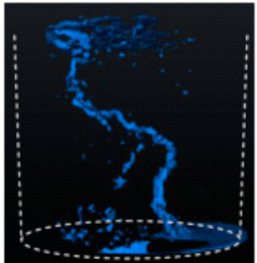

Sample 102, $Q=1 \mathrm{~cm}^{3} / \mathrm{min}$

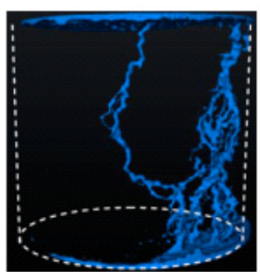

Sample 135 , $Q=1 \mathrm{~cm}^{3} / \mathrm{min}$

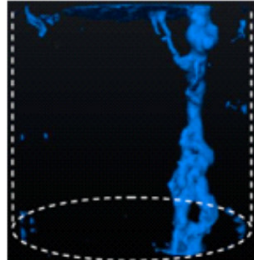

Sample 73 $Q=5 \mathrm{~cm}^{3} / \mathrm{min}$

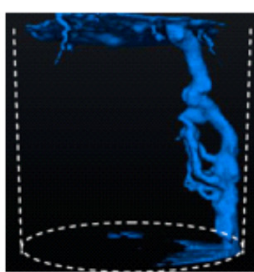

Sample 118, $Q=5 \mathrm{~cm}^{3} / \mathrm{min}$

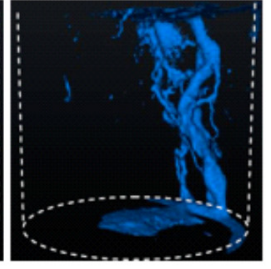

Sample 74 $Q=\mathrm{cm}^{3} / \mathrm{min}$

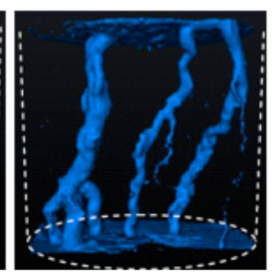

Sample 128, $Q=10 \mathrm{~cm}^{3} / \mathrm{min}$

Fig. 6. The comparison of wormhole development structures depending on the $15 \%$ acid injection rate

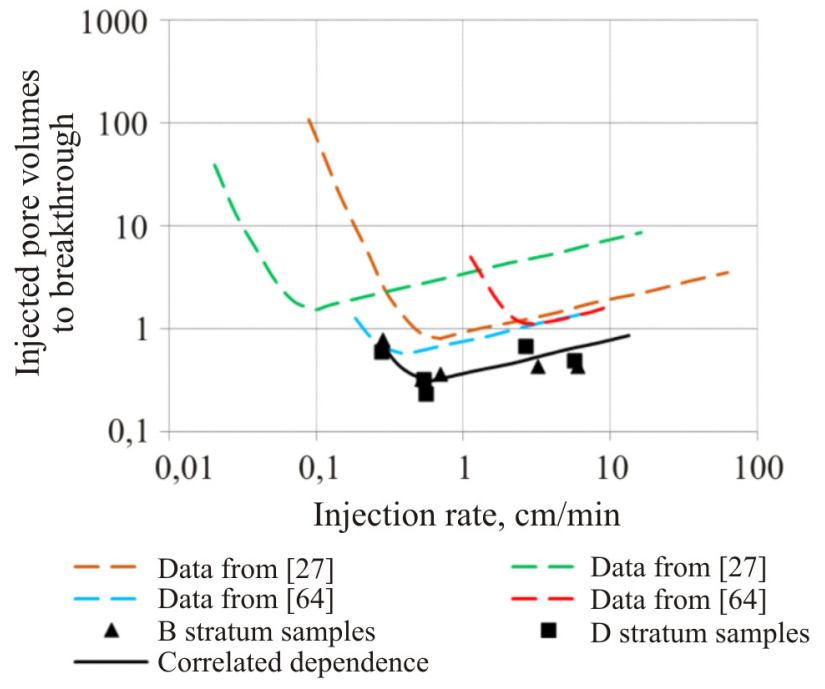

Fig. 7. Result of comparison of the performed experiments (black curve) and data provided in [27, 64]

\section{Conclusions}

1. Multiple instances of research have shown that any given rock-acid compound system has an optimum injection rate that helps form long weakly ramified flow channels (wormholes) at a minimum acid injection volume (PVBT).

2. The shape and penetration depth of wormholes are influenced by many factors, such as acid solution composition, mineral composition of the rock, formation saturation, rock inhomogeneity, injection rate, well completion type, etc.

3. The factors produce cumulative and at times divergent influence on the acid treatment effectiveness. To obtain the results that can be put into practice, it is necessary to perform tests on the samples selected in the specific field, saturated with fluids that are expected in the NWFR during the HAT, using the solutions planned for injection, at pressure and temperature values expected during the HAT.

4. In order to design a HAT for an Iraqi field, the tests have been performed to assess the influence of the acid concentration and injection rate on the acid treatment effectiveness in the conditions approximating to those expected during the HAT.

5. At a linear injection rate of $0.5 \mathrm{~cm} / \mathrm{min}$, the most optimum wormhole structure for the conditions of the field under study is formed at a low acid concentration.

6. The optimum $15 \%$ hydrochloric acid injection rate for the tested samples amounted to $0.6 \mathrm{~cm} / \mathrm{min}$.

7. The obtained results have been successfully used for HAT design in 19 wells as the input data for the acid treatment modelling.

\section{References}

1. Chang F. Technology focus: matrix stimulation. Society of Petroleum Engineers, 2017, June 1. DOI: 10.2118/0617-0064-JPT

2. Glushchenko V.N., Silin M.A. Neftepromyslovaia khimiia. Vol.4. Kislotnaia obrabotka skvazhin [Oilfield chemistry. Vol.4. Well acid treatment]. Moscow, Interkontakt nauka, 2010, $703 \mathrm{p}$.

3. Surguchev M.L., Kolganov V.I., Gavura A.V. Izvlechenie nefti iz karbonatnykh kollektorov 
[Oil recovery from carbonate reservoirs]. Moscow, Nedra, 1987, $230 \mathrm{p}$.

4. Davydov A.B., Chernitskii A.B. Razrabotka mestorozhdenii $\mathrm{s}$ karbonatnymi kollektorami: tekushchee sostoianie, problemy, perspektivy [Development of deposits with carbonate reservoirs: current status, problems and prospects]. Oil industry, 1993, no.3, pp.18-21.

5. Kirkinskaia V.N., Smekhov E.M. Karbonatnye porody-kollektory nefti i gaza [Carbonate oil and gas reservoir rocks]. Leningrad, Nedra, 1981, 255 p.

6. Aidagulov G., Qiu X., Brady D., Abbad M., Onel Y., Ewert U. New insights into carbonate matrix stimulation from high-resolution 3D images of wormholes obtained in radial acidizing experiments. Society of Petroleum Engineers, 2018, August 16. DOI: 10.2118/192366-MS

7. Seagraves A.N., Smart M.E., Ziauddin M.E. Fundamental wormhole characteristics in acid stimulation of perforated carbonates Society of Petroleum Engineers, 2018, February 7. DOI: $10.2118 / 189506-\mathrm{MS}$

8. McDuff D., Shuchart C.E., Jackson S., Postl D., Brown J.S. Understanding wormholes in carbonates: unprecedented experimental scale and 3-D visualization. Society of Petroleum Engineers, 2010, January 1. DOI: 10.2118/134379-MS

9. Wang Y., Hill A.D., Schechter R.S. The optimum injection rate for matrix acidizing of carbonate formations Society of Petroleum Engineers, 1993, January 1. DOI: 10.2118/26578-MS

10. Frick T.P., Mostofizadeh B., Economides M.J. Analysis of radial core experiments for hydrochloric acid interaction with limestones Society of Petroleum Engineers, 1994, January 1. DOI: $10.2118 / 27402-\mathrm{MS}$

11. Mostofizadeh B., Economides M.J. Optimum injection rate from radial acidizing experiments Society of Petroleum Engineers, 1994, January 1. DOI: 10.2118/28547-MS

12. Fredd C.N., Miller M.J. Validation of carbonate matrix stimulation models Society of Petroleum Engineers, 2000, January 1. DOI:10.2118/58713-MS

13. Mishchenkov I.S., Troshkov S.A. Vliianie skorosti dvizheniia solianoi kisloty na skorost rastvoreniia karbonatnoi porody [Effect of the movement rate of hydrochloric acid on the carbonate rock dissolution rate]. Oil industry, 1986, no.5, pp.48-49.
14. Orlov N.N., Turiianov A.R., Zagirov R.R., Prochukhan K.Iu., Prochukhan Iu.A. Podbor optimalnoi kislotnoi kompozitsii dlia provedeniia kislotnogo vozdeistviia na nizkopronitsaemykh karbonatnykh kollektorakh [Selection of the optimal acid composition for acidizing low permeable carbonate reservoirs]. Oilfield engineering, 2017, no.3. pp.37-42.

15. Glushchenko V.N., Khizhniak G.P. Solianokislyi sostav $\mathrm{s}$ ispolzovaniem lingosulfonatov tekhnicheskikh dlia obrabotki prizaboinoi zony [Hydrochloric acid composition with usage of technical lignosulfites to treat formation critical zone]. Geology, geophysics and development of oil and gas fields, 2010, no.9. pp.55-60.

16. Dong K., Zhu D., Hill A.D. Theoretical and experimental study on optimal injection rates in carbonate acidizing. Society of Petroleum Engineers, 2016, February 24. DOI: $10.2118 / 178961-\mathrm{MS}$

17. Bazin B. From matrix acidizing to acid fracturing: a laboratory evaluation of acid/rock interactions. Society of Petroleum Engineers, 2001, February 1. DOI: 10.2118/66566-PA

18. Fredd C.N., Fogler H.S. Optimum conditions for wormhole formation in carbonate porous media: influence of transport and reaction. Society of Petroleum Engineers, 1999, September 1. DOI: $10.2118 / 56995-P A$

19. Gadiyar B.R., Civan F. Acidization-induced formation damage: experimental and modeling studies. Society of Petroleum Engineers, 1994, January 1. DOI: 10.2118/27400-MS

20. Cheng H., Zhu D., Hill A.D. The effect of evolved $\mathrm{CO}_{2}$ on wormhole propagation in carbonate acidizing. Society of Petroleum Engineers, 2016, February 24. DOI: 10.2118/178962-MS

21. Shukla S., Zhu D., Hill A.D. Gas assisted acidizing of carbonate formations. Society of Petroleum Engineers, 2003, January 1. DOI: $10.2118 / 82273-\mathrm{MS}$

22. Kumar R., He J., Nasr-El-Din H. New insights on the effect of oil saturation on the optimum acid injection rate in carbonate acidizing. Society of Petroleum Engineers, 2014, April 12. DOI: $10.2118 / 169134-\mathrm{MS}$

23. Almutairi S., Al-Obied M.A., AlYami I., Shebatalhamd A., Al-Shehri D.A. Wormhole propagation in tar during matrix acidizing of carbonate 
formations. Society of Petroleum Engineers, 2012, January 1. DOI: 10.2118/151560-MS

24. Kumar R., He J., Nasr-El-Din H. Effect of oil saturation on acid propagation during matrix acidization of carbonate rocks. Society of Petroleum Engineers, 2014, May 21. DOI: $10.2118 / 169330-\mathrm{MS}$

25. Ahmed M., Sultan A., Qiu X., Sidaoui Z., Ali A.-A. A novel emulsified acid for deep wells stimulation: rheology, stability, and coreflood study. Society of Petroleum Engineers, 2018, August 16. DOI: 10.2118/192312-MS

26. Daeffler C.S., del Valle J. F., Kariampally J., Elkhoury J.E., Max N., Panga M. Improving wormholing efficiency in carbonates with a novel system based on hydrochloric acid. Society of Petroleum Engineers, 2018, February 7. DOI: $10.2118 / 189540-\mathrm{MS}$

27. Fredd C.N., Tjia R., Fogler H.S. The existence of an optimum damkohler number for matrix stimulation of carbonate formations. Society of Petroleum Engineers, 1997, January 1. DOI: $10.2118 / 38167-M S$

28. Vakhrushev S.A., Folomeev A.E., Kotenev Iu.A., Nabiullin R.M. Issledovanie kislotnogo vozdeistviia $\mathrm{s}$ primeneniem potokootklonitelei na karbonatnye kollektory mestorozhdeniia im. R. Trebsa [Acid treatment with diverting on carbonate reservoirs of R. Trebs oil field]. Oil industry, 2016, no.4, pp.112-117.

29. Khizhniak G.P., Amirov A.M., Gladkikh E.A., Kolesov V.A., Zakharian A.G., Chikin A.E., Kharris R. Issledovanie vozdeistviia kislotogeneriruiushchego sostava na kerny produktivnykh otlozhenii Kuiumbinskogo litsenzionnogo uchastka [Study of the acid-generating composition effect on the cores of the productive deposits of the Kuyumbinskiy license area]. Oil industry, 2015, no. 3, pp.31-35.

30. Khizhniak G.P., Ponomareva I.N., Amirov A.M., Iliushin P.Iu., Glushchenko V.N., Ptashko O.A. Filtratsionnye issledovaniia novykh kislotnykh sostavov dlia obrabotki karbonatnykh kollektorov [Filtration studies of new compounds for the treatment of acid carbonate reservoirs]. Oil industry, 2013, no.11, pp.116-119.

31. Khizhniak G.P., Ponomareva I.N., Amirov A.M., Glushchenko V.N. Opredelenie optimalnoi skorosti zakachki kislotnykh sostavov po rezultatam issledovanii na kernakh [Determination of the optimal rate of injection acid compositions on the results of research on the core samples]. Oil industry, 2014, no.6, pp.52-54.

32. Rogachev M.K., Lenchenkov N.S., Petrov D.A., Lenchenkova L.E., Akchurin Kh.I. Obosnovanie primeneniia $\mathrm{V}$ karbonatnykh kollektorakh potokootkloniaiushchikh tekhnologii na osnove kislotnykh geleobrazuiushchikh sostavov [Justification of implementation of water control technology by using acid gel compounds in carbonate rocks]. Oil industry, 2012, no.8, pp.129-131.

33. Kinziabulatova K.A., Apkarimova G.I., Shafikova E.A., Prochukhan K.Iu., Prochukhan Iu.A. Geleobrazuiushchie agenty, primeniaemye pri kislotnoi obrabotke [Gel-forming agents used during acid treatment]. Oilfield engineering, 2016, no.11, pp.39-43.

34. Shipilov A.I., Krutikhin E.V., Kudrevatykh N.V., Mikov A.I. Novye kislotnye sostavy dlia selektivnoi obrabotki porovo-treshchinovatykh kollektorov [New acid compositions for selective treatment of carbonate reservoir]. Oil industry, 2012, no.2, pp.80-83.

35. Rakhmanov R.M., Ismagilov F.Z., Farkhutdinov G.N., Khisamutdinov A.I., Musabirov M.Kh., Abusalimov E.M. Razrabotka usovershenstvovannykh kislotnykh stimuliruiushchikh kompozitsii "KSK-Tatneft" [Development of KSK-Tatneft improved acidizing compositions]. Oil industry, 2012, no.3, pp.74-77.

36. Mishchenkov I.S. Ob osobennostiakh vozdeistviia solianokislotnoi penoi na karbonatnuiu sredu [About the features of the effect of hydrochloric acid foam on the carbonate medium]. Oil industry, 1994, no.1, pp.63-64.

37. Vasiasin G.I., Nasibulin I.M., Korniltsev Iu.A., Baimashev B.A., Zaripov R.R., Kruglov M.P., Khairtdinov R.K. Podbor effektivnykh kislotnykh sostavov dlia obrabotki prizaboinykh zon skvazhin $\mathrm{v}$ karbonatnykh kollektorakh [Selection of effective acid compositions for treating bottom-hole zones of wells in carbonate reservoirs]. Oilfield engineering, 2009, no.4, pp.17-21.

38. Nasibulin I.M., Vasiasin G.I., Baimashev B.A., Akhmetzianov R.R., Kharitonov R.R. Povyshenie effektivnosti obrabotok produktivnykh plastov kompozitsiiami na osnove solianoi kisloty [Improving the efficiency of treatment of 
productive formations with compositions based on hydrochloric acid]. Oilfield engineering, 2008, no. 8 , pp. 25-27.

39. Gainetdinov R.F., Rakhimov R.L., Nasibulin I.M. Povyshenie effektivnosti kislotnogo vozdeistviia na osnovanii rezultatov issledovaniia kerna [Improving efficiency of acidizing based on core research results]. Geology, Geophysics and Development of Oil and Gas Fields, 2012, no.11, pp.46-52.

40. Nasibulin I.M., Misolina N.A., Baimashev B.A. Sovremennye predstavleniia o vliianii geologicheskikh faktorov, opredeliaiushchikh protsess vzaimodeistviia kislotnykh rastvorov $\mathrm{s}$ karbonatnoi porodoi [Modern views on the influence of geological factors determining the process of interaction of acid solutions with carbonate rock]. Geology, Geophysics and Development of Oil and Gas Fields, 2011, no.3, pp.56-61.

41. Kharisov R.Ia., Bulgakova G.T., Sharifullin A.R., Makatrov A.K., Telin A.G., Pestrikov A.V. Fizicheskoe modelirovanie tekhnologii vodoizoliatsii treshchin dlia posleduiushchei kislotnoi stimuliatsii skvazhin $\mathrm{v}$ karbonatnykh kollektorakh [Physical modeling of fracture water shutoff technology for the next acid stimulation of wells drilled in carbonate formations]. Geology, Geophysics and Development of Oil and Gas Fields, 2010, no.7, pp.44-50.

42. Glushchenko V.N., Ptashko O.A. Filtratrion research of novel acidic compounds for treatment of carbonate reservoirs. Perm Journal of Petroleum and Mining Engineering, 2014, no.11, pp.46-56.

43. Solodovnikov A.O., Andreev O.V., Kiselev K.V. Vliianie skorosti zakachki rastvorov kislotoobrazuiushchikh reagentov na strukturu kanalov filtratsii [Influence of pumping rate of acidforming reagents solutions on channel filtration structure]. Bashkirskii khimicheskii zhurnal, 2013, vol.24, no.1. pp.135-137.

44. Nino-Penaloza A., Gomaa A.M. New insights on chemical diversion in carbonate acidizing: experimental and simulation-based study. Society of Petroleum Engineers, 2016, September 26. DOI: 10.2118/181485-MS

45. Ameri A., Raoof A., Blonk C., Cnudde V. Detailed modeling of carbonate acidizing by coupling a multi-purpose pore-network simulator to the chemistry package PHREEQC application to chelating Agents. Society of Petroleum Engineers, 2017, May 17. DOI: $10.2118 / 185532-\mathrm{MS}$

46. Li X., Chen Y., Yang Z., Chen F. Large-scale visual experiment and numerical simulation of acid fingering during carbonate acid fracturing. Society of Petroleum Engineers, 2017, October 17. DOI: 10.2118/187019-MS

47. Abdelfatah E., Bang S., Pournik M., Shiau B.J., Harwell J., Haroun M., Rahman M. Acid diversion in carbonates with nanoparticles-based in situ gelled acid. Society of Petroleum Engineers, 2017, November 13. DOI: $10.2118 / 188188-M S$

48. Sazali Y., Misra S., Sazali W.L., Ibrahim J.M., Graham G.M., Kidd S.L., Gödeke S. Evaluation of the effectiveness of matrix stimulation recipes for high $\mathrm{CO}_{2}$ carbonate reservoirs for bypassing formation damage. Society of Petroleum Engineers, 2018, February 7. DOI: 10.2118/189567-MS

49. Huang J., Safari R., Fragachan F.E. Applications of self-degradable particulate diverters in wellbore stimulations: hydraulic fracturing and matrix acidizing case studies. Society of Petroleum Engineers, 2018, October 16. DOI: 10.2118/191408-18IHFT-MS

50. Karale C., Beuterbaugh A., Pinto M., Hipparge G., Prakash A. HP/HT carbonate acidizing - recent discoveries and contradictions in wormhole phenomenon. Offshore Technology Conference, 2016, March 22. DOI: $10.4043 / 26714-M S$

51. Qiu X., Edelman E., Aidagulov G., Ghommem M., Brady D., Abbad M. Experimental investigation of radial and linear acid injection into carbonates for well stimulation Operations. Society of Petroleum Engineers, 2018, August 16. DOI: 10.2118/192261-MS

52. Aidagulov G., Gwaba D., Kayumov R., Sultan A., Aly M., Qiu X., Abbad M. Effects of pre-existing fractures on carbonate matrix stimulation studied by large-scale radial acidizing experiments. Society of Petroleum Engineers, 2019, March 15. DOI: 10.2118/195153-MS

53. McDuff D., Jackson S., Shuchart C., Postl D. Understanding wormholes in carbonates: unprecedented experimental scale and 
3D-visualization. Society of Petroleum Engineers, 2010, October 1. DOI: 10.2118/129329-JPT

54. Postnikov A.V., Kosmynin V.A. Izmenenie kollektorskikh svoistv $\mathrm{V}$ rezultate kislotnoi obrabotki [Change in reservoir properties as a result of acid treatment]. Trudy $R G U$ nefti $i$ gaza im. I.M. Gubkina, 2009, № 1/254, pp.7-14.

55. Izgec O., Keys R.S., Zhu D., Hill A.D. An integrated theoretical and experimental study on the effects of multiscale heterogeneities in matrix acidizing of carbonates. Society of Petroleum Engineers, 2008, January 1. DOI: $10.2118 / 115143-M S$

56. Izgec O., Zhu D., Hill A.D. Models and methods for understanding of early acid breakthrough observed in acid core-floods of vuggy carbonates. Society of Petroleum Engineers, 2009, January 1. DOI: 10.2118/122357-MS

57. Dubetz D., Cheng H., Zhu D., Hill A.D. Characterization of rock pore-size distribution and its effects on wormhole propagation. Society of Petroleum Engineers, 2016, September 26. DOI: $10.2118 / 181725-\mathrm{MS}$

58. Etten J., Zhu D., Hill A.D. The combined effect of permeability and pore structure on carbonate matrix Acidizing. Society of Petroleum Engineers, 2015, June 1. DOI: 10.2118/174314-MS

59. Iazynina I.V., Sheliago E.V., Chertenkov M.V., Ivanishin I.B. Fizicheskoe modelirovanie protsessov intensifikatsii dobychi iz karbonatnykh kollektorov [Physical modeling of production stimulation in carbonate reservoirs]. Oil industry, 2015, no.9, pp.92-95.

60. Chertenkov M.V., Aleroev A.A., Ivanishin I.B., Iazynina I.V., Sheliago E.V. Fizicheskoe modelirovanie protsessov intensifikatsii dobychi $\mathrm{v}$ nizkopronitsaemykh karbonatnykh kollektorakh [Physical modeling of production stimulation in low permeability carbonate reservoirs]. Oil industry, 2015, no.10, pp.90-92.

61. Ridner D., Frick T., Zhu D., Hill A.D., Angeles R., Vishnumolakala N., Shuchart C. Influence of transport conditions on optimal injection rate for acid jetting in carbonate Reservoirs. Society of Petroleum Engineers, 2018, February 7. DOI: 10.2118/189546-MS

62. Bartko K.M., Chang F.F., Behrmann L.A., Walton I.C. Effective matrix acidizing in carbonate reservoir - does perforating matter? Society of Petroleum Engineers, 2007, January 1. DOI: 10.2118/105022-MS

63. Diaz N.J., Bell M.R., Hardesty J.T., Hill A.D., Nasr-El-Din H.A. An evaluation of the impact of reactive perforating charges on acid wormholing in carbonates. Society of Petroleum Engineers, 2010, January 1. DOI: $10.2118 / 138434-\mathrm{MS}$

64. Buijse M.A., Glasbergen G. A semiempirical model to calculate wormhole growth in carbonate acidizing. Society of Petroleum Engineers, 2005, January 1. DOI: 10.2118/96892-MS

65. Qiu X.W., Zhao W., Dyer S.J., Al Dossary A., Khan S., Sultan A.S.Revisiting reaction kinetics and wormholing phenomena during carbonate acidizing. International Petroleum Technology Conference, 2014, January 19. DOI: 10.2523/IPTC-17285-MS

66. Khuzin R., Shevko N., Melnikov S. Improving well stimulation technology based on acid stimulation modeling, lab and field data integration. Society of Petroleum Engineers, 2019, October, 196976-MS.

\section{Библиографический список}

1. Chang F. Technology focus: matrix stimulation. Society of Petroleum Engineers, 2017, June 1. DOI: 10.2118/0617-0064-JPT

2. Глущенко В.Н., Силин М.А. Нефтепромысловая химия: в 5 т. Т. 4. Кислотная обработка скважин. - М.: Интерконтакт Наука, 2010. - 703 с.

3. Сургучев М.Л., Колганов В.И., Гавура А.В. Извлечение нефти из карбонатных коллекторов. М.: Недра, 1987. - 230 с.

4. Давыдов А.В., Черницкий А.В. Разработка месторождений с карбонатными коллекторами:
Текущее состояние, проблемы, перспективы // Нефтяное хозяйство. - 1993. - № 3. - С. 18-21.

5. Киркинская В.Н., Смехов Е.М. Карбонатные породы-коллекторы нефти и газа. - Л.: Недра, 1981. - 255 с.

6. New insights into carbonate matrix stimulation from high-resolution 3D images of wormholes obtained in radial acidizing experiments / G. Aidagulov, X. Qiu, D. Brady, M. Abbad, Y. Onel, U. Ewert // Society of Petroleum Engineers. 2018. - August 16. DOI: 10.2118/192366-MS 
7. Seagraves A.N., Smart M.E., Ziauddin M.E. Fundamental wormhole characteristics in acid stimulation of perforated carbonates // Society of Petroleum Engineers. - 2018. - February 7. DOI: $10.2118 / 189506-M S$

8. Understanding wormholes in carbonates: unprecedented experimental scale and 3-D visualization / D. McDuff, C.E. Shuchart, S. Jackson, D. Postl, J.S. Brown // Society of Petroleum Engineers. - 2010. January 1. DOI: 10.2118/134379-MS

9. Wang Y., Hill A.D., Schechter R.S. The optimum injection rate for matrix acidizing of carbonate formations // Society of Petroleum Engineers. - 1993. January 1. DOI: 10.2118/26578-MS

10. Frick T.P., Mostofizadeh B., Economides M.J. Analysis of radial core experiments for hydrochloric acid interaction with limestones // Society of Petroleum Engineers. - 1994. - January 1. DOI: 10.2118/27402-MS

11. Mostofizadeh B., Economides M.J. Optimum injection rate from radial acidizing experiments // Society of Petroleum Engineers. - 1994. - January 1. DOI: $10.2118 / 28547-M S$

12. Fredd C.N., Miller M.J. Validation of carbonate matrix stimulation models // Society of Petroleum Engineers. - 2000. - January 1. DOI:10.2118/58713-MS

13. Мищенков И.С., Трошков С.А. Влияние скорости движения соляной кислоты на скорость растворения карбонатной породы // Нефтяное хозяйство. -1986 . - № 5. - С. 48-49.

14. Подбор оптимальной кислотной композиции для проведения кислотного воздействия на низкопроницаемых карбонатных коллекторах / Н.Н. Орлов, А.Р. Туриянов, Р.Р. Загиров, К.Ю. Прочухан, Ю.А. Прочухан // Нефтепромысловое дело. - 2017. - № 3. - С. 37-42.

15. Глущенко В.Н., Хижняк Г.П. Солянокислый состав с использованием лигносульфонатов технических для обработки призабойной зоны // Геология, геофизика и разработка нефтяных и газовых месторождений. 2010. - № 9. - С. 55-60.

16. Dong K., Zhu D., Hill A.D. Theoretical and experimental study on optimal injection rates in carbonate acidizing // Society of Petroleum Engineers. 2016. - February 24. DOI: 10.2118/178961-MS

17. Bazin B. From matrix acidizing to acid fracturing: a laboratory evaluation of acid/rock interactions // Society of Petroleum Engineers. 2001. - February 1. DOI: 10.2118/66566-PA
18. Fredd C.N., Fogler H.S. Optimum conditions for wormhole formation in carbonate porous media: influence of transport and reaction // Society of Petroleum Engineers. - 1999. - September 1. DOI: $10.2118 / 56995-P A$

19. Gadiyar B.R., Civan F. Acidization-induced formation damage: experimental and modeling studies // Society of Petroleum Engineers. - 1994. January 1. DOI: 10.2118/27400-MS

20. Cheng H., Zhu D., Hill A.D. The effect of evolved $\mathrm{CO}_{2}$ on wormhole propagation in carbonate acidizing // Society of Petroleum Engineers. 2016. - February 24. DOI: 10.2118/178962-MS

21. Shukla S., Zhu D., Hill A.D. Gas assisted acidizing of carbonate formations // Society of Petroleum Engineers. - 2003. - January 1. DOI: $10.2118 / 82273-\mathrm{MS}$

22. Kumar R., He J., Nasr-El-Din H. New insights on the effect of oil saturation on the optimum acid injection rate in carbonate acidizing // Society of Petroleum Engineers. - 2014. - April 12. DOI: 10.2118/169134-MS

23. Wormhole propagation in tar during matrix acidizing of carbonate formations / S. Almutairi, M.A. Al-Obied, I. AlYami, A. Shebatalhamd, D.A. Al-Shehri // Society of Petroleum Engineers. 2012. - January 1. DOI: 10.2118/151560-MS

24. Kumar R., He J., Nasr-El-Din H. Effect of oil saturation on acid propagation during matrix acidization of carbonate rocks // Society of Petroleum Engineers. - 2014. - May 21. DOI: $10.2118 / 169330-M S$

25. A novel emulsified acid for deep wells stimulation: rheology, stability, and coreflood study / M. Ahmed, A. Sultan, X. Qiu, Z. Sidaoui, A.-A. Ali // Society of Petroleum Engineers. - 2018. - August 16. DOI: 10.2118/192312-MS

26. Improving wormholing efficiency in carbonates with a novel system based on hydrochloric acid / C.S. Daeffler, J.F. del Valle, J. Kariampally, J.E. Elkhoury, N. Max, M. Panga // Society of Petroleum Engineers. 2018. - February 7. DOI: 10.2118/189540-MS

27. Fredd C.N., Tjia R., Fogler H.S. The existence of an optimum damkohler number for matrix stimulation of carbonate formations // Society of Petroleum Engineers. - 1997. - January 1. DOI: $10.2118 / 38167-\mathrm{MS}$

28. Исследование кислотного воздействия с применением потокоотклонителей на карбонат- 
ные коллекторы месторождения им. Р. Требса / С.А. Вахрушев, А.Е. Фоломеев, Ю.А. Котенев, Р.М. Набиуллин // Нефтяное хозяйство. - 2016. № 4. - С. 112-116.

29. Исследование воздействия кислотогенерирующего состава на керны продуктивных отложений Куюмбинского лицензионного участка / Г.П. Хижняк, А.М. Амиров, Е.А. Гладких, В.А. Колесов, А.Г. Захарян, А.Е. Чикин, Р. Харрис // Нефтяное хозяйство. - 2015. - № 3. - С. 31-35.

30. Фильтрационные исследования новых кислотных составов для обработки карбонатных коллекторов / Г.П. Хижняк, И.Н. Пономарева, А.М. Амиров, П.Ю. Илюшин, В.Н. Глущенко, О.А. Пташко // Нефтяное хозяйство. - 2013. № 11. - С. 116-119.

31. Определение оптимальной скорости закачки кислотных составов по результатам исследований на кернах / Г.П. Хижняк, И.Н. Пономарева, А.М. Амиров, В.Н. Глущенко // Нефтяное хозяйство. - 2014. - № 6. - С. 52-54.

32. Обоснование применения в карбонатных коллекторах потокоотклоняющих технологий на основе кислотных гелеобразующих составов / М.К. Рогачев, Н.С. Ленченков, Д.А. Петров, Л.Е. Ленченкова, Х.И. Акчурин // Нефтяное хозяйство. - 2012. - № 8. - С. 129-131.

33. Гелеобразующие агенты, применяемые при кислотной обработке / К.А. Кинзябулатова, Г.И. Апкаримова, Е.А. Шафикова, К.Ю. Прочухан, Ю.А. Прочухан // Нефтепромысловое дело. 2016. - № 11. - C. 39-43.

34. Новые кислотные составы для селективной обработки порово-трещиноватых коллекторов / А.И. Шипилов, Е.В. Крутихин, Н.В. Кудреватых, А.И. Миков // Нефтяное хозяйство. - 2012. №2. - C. $80-83$.

35. Разработка усовершенствованных кислотных стимулирующих композиций «КСК-Татнефть» / Р.М. Рахманов, Ф.З. Исмагилов, Г.Н. Фархутдинов, А.И. Хисамутдинов, М.Х. Мусабиров, Э.М. Абусалимов // Нефтяное хозяйство. 2012. - № 3. - С. 74-77.

36. Мищенков И.С. Об особенностях воздействия солянокислотной пеной на карбонатную среду // Нефтяное хозяйство. 1994. - № 1. - С. 63-64.

37. Подбор эффективных кислотных составов для обработки призабойных зон скважин в карбонатных коллекторах / Г.И. Васясин,
И.М. Насибулин, Ю.А. Корнильцев, Б.А. Баймашев, Р.Р. Зарипов, М.П. Круглов, Р.К. Хайртдинов // Нефтепромысловое дело. - 2009. - № 4. C. $17-21$.

38. Повышение эффективности обработок продуктивных пластов композициями на основе соляной кислоты / И.М. Насибулин, Г.И. Васясин, Б.А. Баймашев, Р.Р. Ахметзянов, Р.Р. Харитонов // Нефтепромысловое дело. - 2008. - № 8. C. 25-27.

39. Гайнетдинов Р.Ф., Рахимов Р.Л., Насибулин И.М. Повышение эффективности кислотного воздействия на основании результатов исследования керна // Геология, геофизика и разработка нефтяных и газовых месторождений. - 2012. - № 11. C. $46-52$.

40. Насибулин И.М., Мисолина Н.А., Баймашев Б.А. Современные представления о влиянии геологических факторов, определяющих процесс взаимодействия кислотных растворов с карбонатной породой // Геология, геофизика и разработка нефтяных и газовых месторождений. 2011. - № 3. - С. 56-61.

41. Физическое моделирование технологии водоизоляции трещин для последующей кислотной стимуляции скважин в карбонатных коллекторах / Р.Я. Харисов, Г.Т. Булгакова, А.Р. Шарифуллин, А.К. Макатров, А.Г. Телин, А.В. Пестриков // Геология, геофизика и разработка нефтяных и газовых месторождений. 2010. - № 7. - С. 44-50.

42. Глущенко В.Н., Пташко О.А. Фильтрационные исследования новых кислотных составов для обработки карбонатных коллекторов // Вестник Пермского национального исследовательского политехнического университета. Геология. Нефтегазовое и горное дело. - 2014. - № 11. С. $46-56$.

43. Солодовников А.О., Андреев О.В., Киселев К.В. Влияние скорости закачки растворов кислотообразующих реагентов на структуру каналов фильтрации // Башкирский химический журнал. - 2013. - Т. 24, № 1. C. $135-137$.

44. Nino-Penaloza A., Gomaa A.M. New insights on chemical diversion in carbonate acidizing: experimental and simulation-based study // Society of Petroleum Engineers. - 2016. September 26. DOI: 10.2118/181485-MS 
45. Ameri A., Raoof A., Blonk C., Cnudde V. Detailed modeling of carbonate acidizing by coupling a multi-purpose pore-network simulator to the chemistry package PHREEQC - application to chelating Agents // Society of Petroleum Engineers. - 2017. - May 17. DOI: $10.2118 / 185532-\mathrm{MS}$

46. Li X., Chen Y., Yang Z., Chen F. Largescale visual experiment and numerical simulation of acid fingering during carbonate acid fracturing // Society of Petroleum Engineers. - 2017. October 17. DOI: 10.2118/187019-MS

47. Acid diversion in carbonates with nanoparticles-based in situ gelled acid / E. Abdelfatah, S. Bang, M. Pournik, B.J. Shiau, J. Harwell, M. Haroun, M. Rahman // Society of Petroleum Engineers. - 2017. November 13. DOI: 10.2118/188188-MS

48. Evaluation of the effectiveness of matrix stimulation recipes for high $\mathrm{CO}_{2}$ carbonate reservoirs for bypassing formation damage / Y. Sazali, S. Misra, W.L. Sazali, J.M. Ibrahim, G.M. Graham, S.L. Kidd, S. Gödeke // Society of Petroleum Engineers. - 2018. February 7. DOI: 10.2118/189567-MS

49. Huang J., Safari R., Fragachan F.E. Applications of self-degradable particulate diverters in wellbore stimulations: hydraulic fracturing and matrix acidizing case studies // Society of Petroleum Engineers. - 2018. - October 16. DOI: $10.2118 / 191408-18 I H F T-M S$

50. HP/HT carbonate acidizing - recent discoveries and contradictions in wormhole phenomenon / C. Karale, A. Beuterbaugh, M. Pinto, G. Hipparge, A. Prakash // Offshore Technology Conference. - 2016. - March 22. DOI: $10.4043 / 26714-\mathrm{MS}$

51. Experimental investigation of radial and linear acid injection into carbonates for well stimulation Operations / X. Qiu, E. Edelman, G. Aidagulov, M. Ghommem, D. Brady, M. Abbad // Society of Petroleum Engineers. - 2018. August 16. DOI: 10.2118/192261-MS

52. Effects of pre-existing fractures on carbonate matrix stimulation studied by large-scale radial acidizing experiments / G. Aidagulov, D. Gwaba, R. Kayumov, A. Sultan, M. Aly, X. Qiu, M. Abbad // Society of Petroleum Engineers. - 2019. - March 15. DOI: $10.2118 / 195153-M S$

53. Understanding wormholes in carbonates: unprecedented experimental scale and 3D visualization / D. McDuff, S. Jackson, C. Shuchart, D. Postl // Society of Petroleum Engineers. - 2010. - October 1. DOI: 10.2118/129329-JPT

54. Постников А.В., Космынин В.А. Изменение коллекторских свойств в результате кислотной обработки // Труды РГУ нефти и газа им. И.М. Губкина. - 2009. - № 1/254. - С. 7-13.

55. An integrated theoretical and experimental study on the effects of multiscale heterogeneities in matrix acidizing of carbonates / O. Izgec, R.S. Keys, D. Zhu, A.D. Hill // Society of Petroleum Engineers. - 2008. - January 1. DOI: $10.2118 / 115143-\mathrm{MS}$

56. Izgec O., Zhu D., Hill A.D. Models and methods for understanding of early acid breakthrough observed in acid core-floods of vuggy carbonates // Society of Petroleum Engineers. - 2009. - January 1. DOI: $10.2118 / 122357-\mathrm{MS}$

57. Characterization of rock pore-size distribution and its effects on wormhole propagation / D. Dubetz, H. Cheng, D. Zhu, A.D. Hill // Society of Petroleum Engineers. - 2016. - September 26. DOI: $10.2118 / 181725-\mathrm{MS}$

58. Etten J., Zhu D., Hill A.D. The combined effect of permeability and pore structure on carbonate matrix Acidizing // Society of Petroleum Engineers. 2015. - June 1. DOI: 10.2118/174314-MS

59. Физическое моделирование процессов интенсификации добычи из карбонатных коллекторов / И.В. Язынина, Е.В. Шеляго, М.В. Чертенков, И.Б. Иванишин // Нефтяное хозяйство. -2015 . - № 9. - С. 92-95.

60. Физическое моделирование процессов интенсификации добычи в низкопроницаемых карбонатных коллекторах / М.В. Чертенков, А.А. Алероев, И.Б. Иванишин, И.В. Язынина, Е.В. Шеляго // Нефтяное хозяйство. - 2015. №10. - C. 90-92.

61. Influence of transport conditions on optimal injection rate for acid jetting in carbonate Reservoirs / D. Ridner, T. Frick, D. Zhu, A.D. Hill, R. Angeles, N. Vishnumolakala, C. Shuchart // Society of Petroleum Engineers. - 2018. - February 7. DOI: $10.2118 / 189546-\mathrm{MS}$

62. Effective matrix acidizing in carbonate reservoir - does perforating matter? / K.M. Bartko, F.F. Chang, L.A. Behrmann, I.C. Walton // Society of Petroleum Engineers. - 2007. - January 1. DOI: $10.2118 / 105022-\mathrm{MS}$

63. An evaluation of the impact of reactive perforating charges on acid wormholing in carbonates / 
N.J. Diaz, M.R. Bell, J.T. Hardesty, A.D. Hill, H.A. Nasr-El-Din // Society of Petroleum Engineers. 2010. - January 1. DOI: 10.2118/138434-MS

64. Buijse M.A., Glasbergen G. A semi-empirical model to calculate wormhole growth in carbonate acidizing // Society of Petroleum Engineers. - 2005. January 1. DOI: 10.2118/96892-MS

65. Revisiting reaction kinetics and wormholing phenomena during carbonate acidizing /
X.W. Qiu, W. Zhao, S.J. Dyer, A. Al Dossary, S. Khan, A.S. Sultan // International Petroleum Technology Conference. - 2014. - January 19. DOI: 10.2523/IPTC-17285-MS

66. Khuzin R., Shevko N., Melnikov S. Improving well stimulation technology based on acid stimulation modeling, lab and field data integration // Society of Petroleum Engineers. 2019. - October. - 196976-MS.

Please cite this article in English as:

Khuzin R.A., Khizhniak G.P. The influence of acid concentration and injection rate on the wormhole development in formation conditions. A laboratory study. Perm Journal of Petroleum and Mining Engineering, 2019, vol.19, no.4, pp.356-372. DOI: $10.15593 / 2224-9923 / 2019.4 .5$

Просьба ссылаться на эту статью в русскоязычных источниках следующим образом:

Хузин Р.А., Хижняк Г.П. Лабораторные исследования влияния концентрации и скорости закачки кислоты на развитие червоточин при пластовых условиях // Вестник Пермского национального исследовательского политехнического университета. Геология. Нефтегазовое и горное дело. - 2019. - Т.19, №4. - С.356-372. DOI: 10.15593/2224-9923/2019.4.5 